\title{
Organizational Commitment in Nigerian Banks: The Influence of Age, Tenure and Education
}

\author{
Benjamin O. Akinyemi ${ }^{1}$ \\ ${ }^{1}$ College of Management and Entrepreneurship, Botswana International University of Science and Technology \\ (BIUST), Palapye, Botswana
}

Correspondence: Benjamin Akinyemi, Department of Industrial Management Systems and Operations, College of Management and Entrepreneurship, Botswana International University of Science of Technology (BIUST), Private Bag 16, Palapye, Botswana. Tel: 267-76-638-791. E-mail: akinyemi.ben@gmail.com

\author{
Received: March 19, 2014 Accepted: August 8, 2014 Online Published: November 26, 2014 \\ doi:10.5539/jms.v4n4p104 URL: http://dx.doi.org/10.5539/jms.v4n4p104
}

\begin{abstract}
This study aimed to examine the influence of age, tenure and education on organizational commitment in a developing country context. Focusing on Nigeria's dynamic banking sector, participants' age, tenure and level of education were measured against the three components of organizational commitment - affective, continuance and normative - in selected commercial banks to determine their relationship. The sample consisted of 303 full-time managerial and non-managerial employees from eight commercial banks located in the South-Western part of Nigeria. The study concludes that older, longer-tenured and more highly educated employees did not report a higher level of commitment than their younger, shorter-tenured and less educated counterparts with regard to affective, continuance and normative commitment. The practical implications of this result and direction for future research with regards to developing countries are discussed.
\end{abstract}

Keywords: organizational commitment, age, tenure, education, commercial banks

\section{Introduction}

Age, tenure and education data are often used by employers to make series of decisions in matters relating to recruitment and selection, salaries and compensation, retrenchment and retirement, etc. In recent times, the Nigerian banking sector has been undergoing series of reforms which have led to restructuring, mergers and acquisitions, downsizing and liquidation. Organizations' management tend to hold the view that the younger the employee the higher the level of commitment and productivity, hence, the preference for the younger to the older employees in acquisition and retention of workforce. Job advertisements do emphasize conditions such as minimum age and educational level not only for entry-level jobs but also for other types of positions. Most job advertisements also specify the added advantage of years of experience. This practice is not unconnected with the general belief that age, tenure and level of education have attitudinal, behavioral and productivity consequences which are critical to organizations' overall performance and sustainability.

The current study examines the role of employee's age, tenure (length of service) and educational levels on the three components of commitment - affective, normative and continuance commitment - in the service industry, Nigeria's banking sector. The study, therefore, is expected to empirically examine the possible influence of employees' demographic factors such as age, tenure and education level influence their affective, normative and continuance commitment. The paper is divided into the following sections: Introduction, Background, Methodology, Result and Discussion, Implications and Future Research.

\section{Background}

\subsection{What is Organizational Commitment?}

The Oxford English Dictionary (1969) defines commitment as “... engagement which restricts freedom from action." Commitment is a person's belief in a cause and pursuing that course willingly, intentionally, voluntarily, actively, passionately and relentlessly. Genuine individual commitment to a cause cannot be enforced or imposed, it is volitional. It is usually the outcome of an individuals' decision-making process during which the particular cause is weighed against interest, desired outcome, perceived cost and/or benefit. Kanter (1968) succinctly describes commitment as "the willingness of social actors to give their energy and loyalty to social systems, the 
attachment of personality systems to social relations, which are seen as self expressive" (p. 500). However, once this binding to a cause has occurred, it could be enhanced and sustained through extrinsic motivational strategies. It is also possible for commitment to wane especially if the initial basis for commitment is not sustained or improved upon according to a person's perception and understanding.

Organizational commitment has been defined in various ways. Broadly defined by Meyer and Herscovitch (2001), it is an incentive that sustains a course of action towards one or more objectives. It is "an attitude or an orientation toward the organization, which links or attaches the identity of the person to the organization" (Sheldon, 1971, p. 143). Viewed as an individual's identification and involvement with an organization, organizational commitment connotes an individual's strong belief in and acceptance of organizational goals and values; readiness to exert considerable effort on behalf of the organization; and a strong desire to remain with the organization (Hart \& Willower, 2001).

This construct is also generally defined in terms of employees' interest in an organization and their connection to it (Meyer \& Allen, 1997, Mowday et al., 1979; Hunt et al., 1989). It connotes identification and involvement with an organization and it has attracted so much attention among contemporary scholars, researchers and practitioners. This growing interest is not unconnected with the construct's well established relationship with other employees' work-related behaviors and attitudes, such as, absenteeism, actual turnover, job satisfaction, extra-role behavior, job involvement and leader-subordinate relations (Arnolds \& Boshoff, 2004; Bagraim, 2003; Buck \& Watson, 2002; Eby et al., 1999; Farrell \& Stamm, 1988; Lance, 1991; Mathieu \& Zajac, 1990; Michaels \& Spector, 1982; Tett \& Meyer, 1993; Wasti, 2003). Organizational commitment has also been found to contribute to employee productivity and organizational performance (Mowday et al., 1982; Allen \& Meyer, 1990; Hackett et al., 1994; Yousef, 2000; Herscovitch \& Meyer, 2002; Shaw et al., 2003).

The survival, success and sustainability of organizations lie in the strong and unalloyed commitment of both internal and external customers. The commitment of the internal customers (i.e., employees) could determine the commitment of organizations' external customers. Fostering internal customers' commitment is, therefore, essential in the unrelenting effort to cope with the competitive pressures generated by rapidly changing business environment. If the culture of commitment is not embeded in organizations' core values the outcome is potentially detrimental. Therefore, modeling and fostering employee commitment should be one of the top priorities of organizations' leadership.

\subsection{A Model of Organizational Commitment}

A three-dimensional model of commitment incorporating affective, continuance and normative commitment was developed by Meyer and Allen (1997, p. 106) to explain different components of organizational commitment and their possible impacts.

\subsubsection{Affective Commitment}

Affective commitment is "the employee's emotional attachment to, identification with, and involvement in the organization" (Meyer \& Allen, p. 11). According to them, an employee who is driven by affective commitment continues to work for the organization because he wants to (Meyer \& Allen, 1991).

\subsubsection{Continuance Commitment}

Continuance commitment is defined as "awareness of the costs associated with leaving the organization" (Meyer \& Allen, 1997, p. 11). It is different from affective commitment dimension in the sense that "employees whose primary link to the organization is based on continuance commitment remain because they need to do so" (Meyer \& Allen, 1991, p. 67). This form of commitment is said to "be the strongest when availability of alternatives are few and the number of investments are high" (Best, 1994, p. 71). Meyer et al. (1990, p. 715) state that "accrued investment and poor employment alternatives tend to force individuals to maintain their line of action and are responsible for these individuals being committed because they need to." Usually, the "need to" stay is based on factors such as employee's age, expectations from personal investment, employer's conditional contractual obligations, like, promotion and pension based on length of service with the organization.

\subsubsection{Normative Commitment}

The third dimension in the model is normative commitment. It is defined as "a feeling of obligation to continue employment" (Meyer \& Allen, 1997, p. 11). In this type of commitment, employees "feel that they ought to remain with the organization" (Meyer \& Allen, 1991, p. 67). Normative commitment has also been described as "the work behavior of individuals, guided by a sense of duty, obligation and loyalty towards the organization" (Wiener and Vardi, 1980, p. 86). Possible causes of this kind feeling may result from an employee's perception of organization's investment in people from which employee has benefitted immensely. 
Reichers (1985), in his classification of commitment, suggest that affective commitment indicates a higher level of commitment while the normative and continuance dimensions of commitment are tantamount to moderate and low levels of commitment respectively.

\subsection{Personal Characteristics and Organizational Commitment}

Empirical studies show the influence of personal characteristics such as age, tenure and education level on employee commitment although there are mixed findings regarding these degrees of influence. For instance, Mathieu and Zajac (1990) reported a low positive correlation between position tenure and OC, medium positive correlation between age and OC and a low negative correlation between education level and OC. However, OC was found to be positively related to age (Steers, 1977; Morris \& Sherman, 1981; Angle \& Perry, 1981; Meyer \& Allen, 1984; Ogba, 2008). Commitment was also found to be positively related to tenure (Buchanan, 1974; Meyer \& Allen, 1984; Mottaz, 1988). Chui et al. (2007) in their survey of 300 ICT professionals in Hong Kong reported that age and tenure do not show any correlation with employee commitment. Sa Abreu et al. (2013) studied the effects of personal characteristics on organizational commitment in Brazil's oil and gas industry. They found that service time and education level are the most significant contributors to continuance commitment. In view of these mixed findings, further empirical investigations are necessary to examine the relationship between personal characteristics on employee commitment, hence, the need for this study.

\section{Methodology}

\subsection{Participants}

The respondents in this study comprise full-time junior and senior employees in the Nigeria banking industry with a diverse distribution in different geographical locations in Nigeria. Self administered questionnaires (with assistance from some managers/officers) numbering 600 were administered with $52 \%$ response rate. Data analysis for this study is based on 303 usable questionnaires out of 310 which were returned by surveyed participants from purposively selected commercial banks.

\subsection{Research Instrument}

The three-component Organizational Commitment (OC) scale of Allen and Meyer's (1993) organizational commitment instrument was used. Sample items of Affective Commitment (AC) sub-scale included "I enjoy discussing my organization with people outside of it" and "This organization has a great deal of personal meaning for me." The Normative Commitment sub-scale consists of items such as: "I do not feel any obligation to remain with my current employer"; "Even if it were to my advantage I do not feel it would be right to leave my organization now", and "This organization deserves my loyalty". The sub-scale of Continuance Commitment (CC) comprise such items as: "I am afraid of what might happen if I quit my job without having another one lined up"; "It would be very hard for me to leave my organization right now, even if I wanted to". Possible responses were arrayed on a five-point Likert scale comprising "strongly disagree" (5), "disagree" (4), "neutral" (3), "agree" (2), and "strongly agree" (1). Test of internal consistency (Cronbach's alpha) was conducted to assess the reliability of the three components of organizational commitment used in this study. The closer the reliabilities coefficient gets to 1.0 , the better. Results indicate that these three components showed adequate levels of internal consistency reliability at $0.87,0.77$ and 0.84 for affective, normative and continuance commitments respectively.

\subsection{Data Analysis}

Data analysis was carried out by using Statistical Package for Social Scientists (SPSS) for Windows. To test the hypotheses, the mean, variance, standard deviation and Pearson Product Moment Correlation Coefficient of all variables were calculated. A one-way ANOVA is used to investigate the differences between means of age, tenure and education level and the three components of the organizational commitment (Garson 1998). A cut-off point of $\mathrm{p}<0.05$ was considered to indicate whether the relationship between the two factors is of statistical significance.

\subsection{Research Model}

Based on the purpose of this study, i. e. examining the influence of Employee characteristics such as age, tenure and education on organizational (Affective, Normative and Continuance) Commitment, a research model (Figure 1) was developed. 


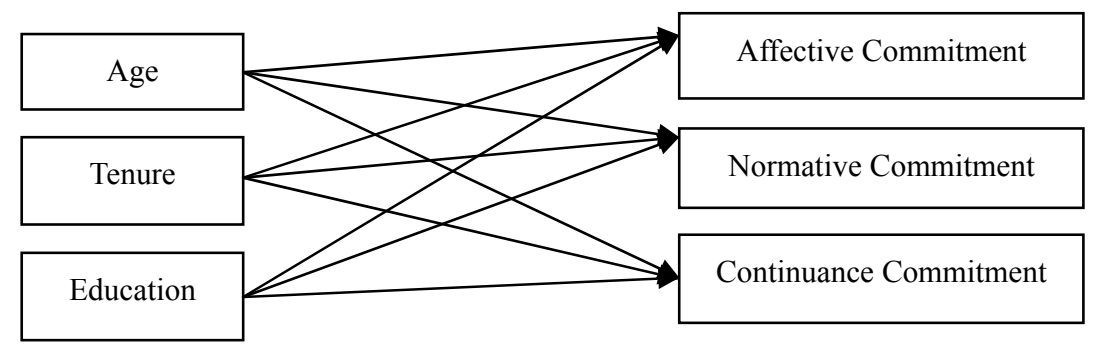

Figure 1. Research model

\subsection{Research Hypotheses}

The study aims to statistically test the following hypotheses:

Hypothesis 1: Older employees will report a higher level of affective, normative and continuance organizational commitment than will employees who are younger.

Hypothesis 2: Longer-tenure employees will score a higher level of affective, normative and continuance organizational commitment than will short-tenure employees.

Hypothesis 3: Employees with higher level of education will report a higher level of affective, normative and continuance organizational commitment than will employees with a lower level of education.

\section{Results and Discussion}

The focus of this study is on organizational commitment as influenced by employees' age, length of service and level of education in Nigerian commercial banks. Findings from this study are stated and discussed as follows:

\subsection{Age and Employee Commitment}

The following findings and discussions relate to the perceived influence of age on employee commitment based on responses from participants. Table 1 shows the age distribution of participants.

Table 1. Age distribution of respondents

\begin{tabular}{ccc}
\hline Age (in years) & Frequency & Percentage \\
\hline below 30 & 94 & 30.3 \\
$31-35$ & 93 & 30.0 \\
$36-39$ & 43 & 13.9 \\
$40-45$ & 38 & 12.3 \\
$46-49$ & 16 & 5.5 \\
$50-55$ & 12 & 3.9 \\
$56-59$ & 5 & 1.6 \\
60 above & 2 & 0.7 \\
Total & 303 & 100 \\
\hline
\end{tabular}

In the table 1 above, $230(76 \%)$ employees are between $<30$ years and 39 years; those between 40 and 55 years are $67(22 \%)$ and those between 56 and $>60$ years are seven $(2.3 \%)$. Younger employees are dominant in term of numbers.

The descriptive analysis in Table 2 shows the influence of age on the commitment of employees to their organizations. 
Table 2. Descriptive analysis of respondents' age and commitment

\begin{tabular}{|c|c|c|c|c|c|c|c|c|c|}
\hline \multirow{3}{*}{$\begin{array}{c}\text { Dimensions } \\
\text { of OC }\end{array}$} & \multirow[t]{3}{*}{ Age (in years) } & \multirow[t]{3}{*}{$\mathrm{N}$} & \multirow[t]{3}{*}{ Mean } & \multirow[t]{3}{*}{ SD } & \multirow[t]{3}{*}{ SE } & \multicolumn{2}{|c|}{$\begin{array}{l}95 \% \text { Confidence } \\
\text { Interval for Mean }\end{array}$} & \multirow[t]{3}{*}{ Minimum } & \multirow[t]{3}{*}{ Maximum } \\
\hline & & & & & & Lower & Upper & & \\
\hline & & & & & & Bound & Bound & & \\
\hline \multirow{9}{*}{$\mathrm{AC}$} & $<30 \mathrm{yrs}$ & 85 & 18.7882 & 4.6447 & .5038 & 17.7864 & 19.7901 & 8.00 & 32.00 \\
\hline & $31-35$ & 87 & 20.5517 & 6.5588 & .7032 & 19.1539 & 21.9496 & 9.00 & 38.00 \\
\hline & $36-39$ & 37 & 20.3514 & 7.2126 & 1.1869 & 17.9442 & 22.7585 & 11.00 & 36.00 \\
\hline & $40-45$ & 33 & 21.9697 & 7.4351 & 1.2943 & 19.3333 & 24.6061 & 10.00 & 37.00 \\
\hline & $46-49$ & 16 & 25.0000 & 7.0143 & 1.7536 & 21.2624 & 28.7376 & 16.00 & 38.00 \\
\hline & $50-55$ & 12 & 19.0000 & 7.7811 & 2.2462 & 14.0561 & 23.9439 & 12.00 & 40.00 \\
\hline & $56-60$ & 5 & 20.4000 & 6.2290 & 2.7857 & 2.7857 & 28.1343 & 15.00 & 31.00 \\
\hline & $>60$ & 2 & 17.0000 & 1.4142 & 1.0000 & 4.2938 & 29.0744 & 16.00 & 18.00 \\
\hline & Total & 277 & 20.3141 & 6.4284 & .3862 & 19.5537 & 21.0744 & 8.00 & 40.00 \\
\hline \multirow{9}{*}{$\mathrm{CC}$} & $<30 \mathrm{yrs}$ & 84 & 258690 & 6.5063 & .7099 & 24.4571 & 27.2810 & 9.00 & 41.00 \\
\hline & $31-35$ & 88 & 26.8977 & 6.7262 & .7170 & 25.4726 & 28.3229 & 13.00 & 43.00 \\
\hline & $36-39$ & 42 & 28.5000 & 7.5716 & 1.1683 & 26.1405 & 30.8595 & 14.00 & 44.00 \\
\hline & $40-45$ & 35 & 26.4571 & 8.0123 & 1.3543 & 23.7048 & 29.2095 & 14.00 & 42.00 \\
\hline & $46-49$ & 17 & 31.824 & 6.2338 & 1.5119 & 28.6772 & 35.0875 & 17.00 & 41.00 \\
\hline & $50-55$ & 11 & 26.3636 & 6.7716 & 2.0417 & 21.8144 & 30.9129 & 13.00 & 39.00 \\
\hline & $56-60$ & 5 & 19.6000 & 5.1284 & 2.2935 & 13.2323 & 25.9677 & 13.00 & 26.00 \\
\hline & $>60$ & 2 & 19.5000 & .7071 & .5000 & 13.1469 & 25.8531 & 19.00 & 20.00 \\
\hline & Total & 284 & 6.8732 & 7.0769 & .4199 & 26.0466 & 27.6998 & 9.00 & 44.00 \\
\hline \multirow{9}{*}{$\mathrm{NC}$} & $<30 \mathrm{yrs}$ & 87 & 15.9195 & 3.8796 & .4159 & 15.0927 & 16.7464 & 6.00 & 25.00 \\
\hline & $31-35$ & 89 & 16.7191 & 4.6490 & .4928 & 15.7398 & 17.6884 & 9.00 & 27.00 \\
\hline & $36-39$ & 39 & 17.2308 & 5.2489 & .8405 & 15.5293 & 18.9323 & 6.00 & 28.00 \\
\hline & $40-45$ & 33 & 17.7273 & 5.6804 & .9888 & 15.7131 & 19.7415 & 9.00 & 30.00 \\
\hline & $46-49$ & 17 & 19.4706 & 5.4327 & 1.3176 & 16.6773 & 22.2638 & 8.00 & 29.00 \\
\hline & $50-55$ & 12 & 17.3333 & 4.5594 & 1.3162 & 14.4364 & 20.2302 & 10.00 & 25.00 \\
\hline & $56-60$ & 5 & 15.0000 & 2.4495 & 1.0954 & 11.9586 & 18.0414 & 12.00 & 18.00 \\
\hline & $>60$ & 2 & 12.5000 & 2.1213 & 1.5000 & -6.5593 & 31.5593 & 11.00 & 14.00 \\
\hline & Total & 284 & 16.7923 & 4.7132 & .2797 & 16.2417 & 17.3428 & 6.00 & 30.00 \\
\hline
\end{tabular}

Note. OC: Organizational Commitment; AC: Affective Commitment; CC: Continuance Commitment; NC: Normative Commitment; N: Number of respondents; SD: Standard Deviation; SE: Standard Error.

According to the statistical results in Table 2, the three levels of commitment is shown to highest among employees within the age bracket $46-49$ years as these employees scored the highest mean scores for each component of commitment (Affective - 16.000; Continuance - 31.8824 and Normative - 19.4706). It should be noted, however, that this category of employees account for only $5.5 \%$ of the participants. This disproportionate number, compared to participants in the age group between $<30$ and 45 years (see table 1) calls for caution in the interpretation of statistical results. Apart from the statistical result that attributes a higher level of commitment to employees within the age bracket $46-49$ years, it is clear that there is hardly any significant difference in the levels of commitment between the younger and older categories of employees (as shown in table 2 above). It could also be explained that the few employees that are within the age brackets of $46-49$ years are, for one reason or the other reach the peak of their commitment to the organization, after which commitment level drops (with increase in age).

Investigating further on the impact of age on commitment, a further statistical analysis was done in which participants were divided into age groups (Table 3). This reports a low significance evidence of statistical significant levels (at $p<0.5$ ) in relationship. For instance, affective commitment, continuance commitment and normative commitment were $.018, .005$ and .078 respectively. Based on this result, it is clear that older employees do not show a higher level of commitment than the younger employees. 
Table 3. One-way ANOVA of employee commitment on age analysis

\begin{tabular}{|c|c|c|c|c|c|c|}
\hline $\begin{array}{c}\text { Dimensions of } \\
\text { OC }\end{array}$ & & Sum of Squares & $\mathrm{df}$ & Mean Square & $\mathrm{F}$ & Sig. \\
\hline \multirow[t]{3}{*}{$\mathrm{AC}$} & Between Groups & 687.367 & 7 & 98.195 & 2.464 & .018 \\
\hline & Within Groups & 10718.308 & 269 & 39.845 & & \\
\hline & Total & 11405.675 & 276 & & & \\
\hline \multirow[t]{3}{*}{$\mathrm{CC}$} & Between Groups & 1004.602 & 7 & 143.515 & 3.008 & .005 \\
\hline & Within Groups & 13168.835 & 276 & 47.713 & & \\
\hline & Total & 14173.437 & 283 & & & \\
\hline \multirow[t]{3}{*}{$\mathrm{NC}$} & Between Groups & 281.458 & 7 & 40.208 & 1.848 & .078 \\
\hline & Within Groups & 6005.285 & 276 & 21.758 & & \\
\hline & Total & 6286.743 & 283 & & & \\
\hline
\end{tabular}

Note. OC: Organizational Commitment; AC: Affective Commitment; CC: Continuance Commitment; NC: Normative Commitment; df: Degree of Freedom; Sig.: Level of Significance.

Thus, hypothesis one is rejected. This is an indication that there are, probably, other factors associated with employee commitment within the investigated Nigerian banking sector rather than the age factor. Some other studies have investigated the influence of age on commitment. A meta-analytic study by Mathieu and Zajac (1990) yielded a medium positive correlation of 0.201 between age and commitment. Others have also reported a positive relationship between commitment and age (Angle and Perry, 1981; Meyer and Allen, 1984; Morris and Sherman, 1981; Steers, 1977; Martin and Roodt, 2008). Zaitouni, et al., (2011) found an insignificant statistical correlation between age and organizational commitment among banks' employees in Kuwait (see Alshitri, 2013). Ogba (2008) found that older employees are less committed compared to their younger counterparts. Salami (2008) investigated the influence of demographic factors in predicting the commitment of Industrial workers in Nigeria. He reported that age significantly correlated with organizational commitment. In a study examining the influence of age on organizational commitment among public servants in Ghana, Adul-Nasiru, et al. (2014) found age to be positively associated with employee commitment.

Past researches have sought to give insight into various findings relating to age and commitment. Rhodes (1983) found age to be associated with inter-related group of effects that influence work attitude and behavior. To explain the reason for the often weak relations between organizational commitment and age Meyer and Allen (1984) argued that younger employees may be more committed because they face fewer job opportunities due to their often less work experience. In the case of the Nigerian banking sector, more empirical studies need to be conducted to justify generalisation of findings.

\subsection{Employees' Tenure and Commitment}

Respondents were grouped into six job tenure categories of $<5$ years $(39.1 \%), 5-10$ years $(30.8 \%), 11-15$ years $(10 \%), 16-20$ years $(14.7 \%), 21-25$ years $(4.3 \%)$ and $>26$ years $(1.1 \%)$. It is observed that with less than five years of tenure form the majority of the respondents while those above 26 years are the least. The more the number of years of work experience the lower the number of employees which is an indication of voluntary or involuntary turnover of more experienced employees within the Nigerian banking sector. It is also a probable indication of job mobility among more experienced bank workers.

Table 4. Tenure distribution of respondents

\begin{tabular}{ccc}
\hline Tenure of Respondents (in Years) & No. of Responses & Percentage \\
\hline$<5$ years & 109 & 39.1 \\
$5-10$ years & 86 & 30.8 \\
$11-15$ years & 28 & 10 \\
$16-20$ years & 41 & 14.7 \\
$21-25$ years & 12 & 4.3 \\
$>26$ years & 3 & 1.1 \\
\hline Total & 279 & 100 \\
\hline
\end{tabular}

Results (in table 5) clearly indicate that employees within the 16-20 years of work experience recorded a higher mean score for the affective (28.5128) and normative (19.2821). The continuance commitment component mean score for this category (28.3559) is virtually the same as for 5-10 years category (28.3951). The category that 
recorded the lowest mean scores for the three components of commitment is 26 - above years (affective: 18.0000; continuance: 19.3333; and normative: 12.3333). It is therefore evident that a low level of commitment is observable among longer-tenured employees than shorter-tenured employees. It should, however be noted that the number of samples in the category of $>26$ years (3) is the least among all the sample categories.

Table 5. Descriptive analysis of respondents' tenure and organizational commitment

\begin{tabular}{|c|c|c|c|c|c|c|c|c|c|}
\hline \multirow{3}{*}{$\begin{array}{l}\text { Dimensions of } \\
\text { OC }\end{array}$} & \multirow{3}{*}{$\begin{array}{l}\text { Tenure (in } \\
\text { years) }\end{array}$} & \multirow[t]{3}{*}{$\mathrm{N}$} & \multirow[t]{3}{*}{ Mean } & \multirow[t]{3}{*}{ SD } & \multirow[t]{3}{*}{ SE } & \multicolumn{2}{|c|}{$\begin{array}{l}95 \% \text { Confidence } \\
\text { Interval for Mean }\end{array}$} & \multirow[t]{3}{*}{ Minimum } & \multirow[t]{3}{*}{ Maximum } \\
\hline & & & & & & Lower & Upper & & \\
\hline & & & & & & Bound & Bound & & \\
\hline \multirow{7}{*}{$\mathrm{AC}$} & $<5$ & 97 & 19.5876 & 5.2495 & .5330 & 18.526 & 20.6456 & 8.00 & 3800 \\
\hline & $5-10$ & 77 & 20.1299 & 6.9800 & .7954 & 18.5456 & 21.7141 & 9.00 & 36.00 \\
\hline & $11-15$ & 25 & 21.4400 & 6.7211 & 1.3442 & 18.6657 & 24.2143 & 11.00 & 35.00 \\
\hline & $16-20$ & 39 & 22.5128 & 8.6811 & 1.3901 & 19.6987 & 25.3269 & 10.00 & 40.00 \\
\hline & $21-25$ & 12 & 20.3333 & 5.1405 & 1.4839 & 17.0672 & 23.5994 & 11.00 & 30.00 \\
\hline & $26+$ & 3 & 18.0000 & 2.6458 & 1.5275 & 11.4276 & 24.5724 & 15.00 & 20.00 \\
\hline & Total & 253 & 20.4032 & 6.5734 & .4133 & 19.5893 & 21.2171 & 8.00 & 40.00 \\
\hline \multirow{7}{*}{$\mathrm{CC}$} & $<5$ & 100 & 25.3500 & 6.2529 & .6253 & 24.1093 & 26.5907 & 13.00 & 41.00 \\
\hline & $5-10$ & 81 & 28.3951 & 7.2692 & .8077 & 26.7877 & 30.0024 & 14.00 & 44.00 \\
\hline & $11-15$ & 25 & 27.6000 & 6.3246 & 1.2649 & 24.9894 & 30.2106 & 15.00 & 42.00 \\
\hline & $16-20$ & 41 & 28.3659 & 8.1356 & 1.2706 & 25.7979 & 30.9338 & 13.00 & 4.00 \\
\hline & $21-25$ & 12 & 25.3333 & 6.0050 & 1.7335 & 21.5179 & 29.1488 & 19.00 & 35.00 \\
\hline & $26+$ & 3 & 19.3333 & 8.5049 & 4.9103 & -1.7940 & 40.4607 & 13.00 & 29.00 \\
\hline & Total & 262 & 26.9084 & 7.0493 & .4355 & 26.0508 & 27.7660 & 1300 & 44.00 \\
\hline \multirow{7}{*}{$\mathrm{NC}$} & $<5$ & 100 & 15.8600 & 4.0101 & .4010 & 15.0643 & 16.6557 & 6.00 & 26.00 \\
\hline & $5-10$ & 83 & 17.3735 & 4.6740 & .5130 & 16.3529 & 18.3941 & 6.00 & 27.00 \\
\hline & $11-15$ & 22 & 17.3182 & 5.1213 & 1.0919 & 15.0475 & 19.5888 & 10.00 & 28.00 \\
\hline & $16-20$ & 39 & 19.2821 & 5.3898 & .8631 & 17.5349 & 21.0292 & 9.00 & 30.00 \\
\hline & $21-25$ & 12 & 17.1667 & 4.2605 & 1.2299 & 14.4597 & 19.8736 & 11.00 & 25.00 \\
\hline & $26+$ & 3 & 12.3333 & 2.5166 & 1.4530 & 6.0817 & 18.5849 & 10.00 & 15.00 \\
\hline & Total & 259 & 17.0039 & 4.6850 & .2911 & 16.4306 & 17.5771 & 6.00 & 30.00 \\
\hline
\end{tabular}

Note. OC: Organizational Commitment; AC: Affective Commitment; CC: Continuance Commitment; NC: Normative Commitment; N: Number of respondents; SD: Standard Deviation; SE: Standard Error.

To further statistically test the second hypothesis, a one-way ANOVA is carried out (Table 6). Results show a low significance evidence for all the three components of commitment, leading to the rejection of the second hypothesis. Supporting this outcome Chughtai and Zafar (2006) and Kura et al. (2012) reported that there was no significant relationship existed between tenure and organizational commitment.

Table 6. One-way ANOVA of employee commitment on tenure analysis

\begin{tabular}{|c|c|c|c|c|c|c|}
\hline $\begin{array}{c}\text { Dimensions } \\
\text { of OC }\end{array}$ & & Sum of Squares & $\mathrm{df}$ & Mean Square & $\mathrm{F}$ & Sig. \\
\hline \multirow[t]{3}{*}{$\mathrm{AC}$} & Between Groups & 288.101 & 5 & 57.620 & 1.343 & .247 \\
\hline & Within Groups & 10600.777 & 247 & 42.918 & & \\
\hline & Total & 10888.877 & 252 & & & \\
\hline \multirow[t]{3}{*}{$\mathrm{CC}$} & Between Groups & 722.848 & 5 & 144.570 & 3.022 & .011 \\
\hline & Within Groups & 12246.954 & 256 & 47.840 & & \\
\hline & Total & 12969.802 & 261 & & & \\
\hline \multirow[t]{3}{*}{$\mathrm{NC}$} & Between Groups & 412.531 & 5 & 82.506 & 3.976 & .002 \\
\hline & Within Groups & 5250.465 & 253 & 20.753 & & \\
\hline & Total & 5662.996 & 258 & & & \\
\hline
\end{tabular}

Note. OC: Organizational Commitment; AC: Affective Commitment; CC: Continuance Commitment; NC: Normative Commitment; df: Degree of Freedom; Sig.: Level of Significance. 
The influence of employee tenure or length of service has also been researched extensively over the years with varying degree and often inconsistent results. Tenure could lead to contemplative commitment because of senior employees' attempt to justify their longer years of working with the organization (Meyer et al., 2002). Cohen (1993) reported a stronger correlation between commitment and length of service among senior employees who have served for nine years or longer. In another study of lower management Reddy and Ravikumar (1980) length of service was found to be positively related to job involvement which is most likely to be the same with commitment. While Mathieu and Zajac, (1990) reported a low positive correlation with commitment, others such as Buchanan (1974), Singhal and Sood (1981), Mottaz (1988), Morris and Sherman (1981) found commitment to be positively related to tenure. Santos and Not-Land (in Salami 2008) and Sepahvand, et al., (2012) also found job tenure to be significantly related to organizational commitment. In contrast, however, Boon et al. (2006) reported a significant negative relationship between commitment and tenured employees.

As dynamic and robust as the Nigerian banking sector is currently, there happens to be very few empirical studies with attitudinal and behavioral focus especially on commitment. Further empirical studies are still required to firmly establish the relationship between different tenure categories and job involvement, especially commitment in the banking sector.

\subsection{Level of Education and Commitment}

Participants were categorized into four different groups of educational levels (Table 7). First (Bachelors) degree (or equivalent) holders account for about two-third (71\%) of the entire respondents. This is followed by Masters' degree (or equivalent) holders and Ordinary National Diploma (or equivalent) holders with $20.5 \%$ and $7.9 \%$ respectively. This shows that the banking sector employs more of Bachelors' degree holders than other categories.

Table 7. Educational levels of respondents

\begin{tabular}{ccc}
\hline Educational Levels & No. of Respondents & Percentage \\
\hline Ordinary National Diploma & 24 & 7.9 \\
First (Bachelors') Degree & 215 & 71 \\
Masters' Degree & 62 & 20.5 \\
Others & 2 & 0.7 \\
\hline Total & 303 & 100 \\
\hline
\end{tabular}

A possible relationship between employees' level of education and organizational commitment was statistically examined (Table 8). Results from this table show that first degree holders or equivalent who form the majority of the sample and most likely to be on their first job and in their first organization indicate a higher level of commitment to work in the three components of commitment (affective: 21.3065; continuance: 27.4363 and normative: 17.5050). A low level of commitment is shown by employees with the lowest level of education while those with Masters' degree show a moderate level of commitment.

Table 8. Descriptive analysis of respondents' education level and commitment

\begin{tabular}{|c|c|c|c|c|c|c|c|c|c|}
\hline \multirow{3}{*}{$\begin{array}{l}\text { Dimensions } \\
\text { of OC }\end{array}$} & \multirow{3}{*}{$\begin{array}{c}\text { Educational } \\
\text { Qualifications }\end{array}$} & \multirow[t]{3}{*}{$\mathrm{N}$} & \multirow[t]{3}{*}{ Mean } & \multirow[t]{3}{*}{$\mathrm{SD}$} & \multirow[t]{3}{*}{ SE } & \multicolumn{2}{|c|}{$\begin{array}{l}95 \% \text { Confidence } \\
\text { Interval for Mean }\end{array}$} & \multirow[t]{3}{*}{ Minimum } & \multirow[t]{3}{*}{ Maximum } \\
\hline & & & & & & Lower & Upper & & \\
\hline & & & & & & Bound & Bound & & \\
\hline \multirow{6}{*}{$\mathrm{AC}$} & National Diploma & 23 & 17.8261 & 4.8491 & 1.0111 & 15.7292 & 19.9230 & 9.00 & 25.00 \\
\hline & Bachelor's Degree & 199 & 21.3065 & 6.7787 & .4805 & 20.3589 & 22.2541 & 8.00 & 40.00 \\
\hline & Masters Degree & 57 & 17.7193 & 4.5855 & .6074 & 16.5026 & 18.9360 & 11.00 & 30.00 \\
\hline & Other & 2 & 19.0000 & .0000 & .0000 & 19.0000 & 19.0000 & 19.00 & 19.00 \\
\hline & Qualifications & & & & & & & & \\
\hline & Total & 281 & 20.2776 & 6.4138 & .3826 & 19.5244 & 21.0307 & 8.00 & 40.00 \\
\hline \multirow{6}{*}{$\mathrm{CC}$} & National Diploma & 23 & 23.8261 & 5.3907 & 1.1240 & 21.4950 & 26.1572 & 9.00 & 35.00 \\
\hline & Bachelor's Degree & 204 & 27.4363 & 7.2974 & .5109 & 26.4289 & 28.4437 & 13.00 & 43.00 \\
\hline & Masters Degree & 59 & 26.1525 & 6.6250 & .8625 & 24.4261 & 27.8790 & 14.00 & 44.00 \\
\hline & Other & 1 & 13.0000 & & & & & 13.00 & 13.00 \\
\hline & Qualifications & & & & & & & & \\
\hline & Total & 287 & 26.8228 & 7.1194 & .4202 & 26.0056 & 27.6599 & 9.00 & 44.00 \\
\hline
\end{tabular}




\begin{tabular}{|c|c|c|c|c|c|c|c|c|c|}
\hline & National Diploma & 24 & 14.6250 & 4.1788 & .8530 & 12.8605 & 16.3895 & 6.00 & 22.00 \\
\hline & Bachelor's Degree & 200 & 17.5050 & 4.9062 & .3469 & 16.8209 & 18.1891 & 6.00 & 30.00 \\
\hline \multirow[t]{4}{*}{$\mathrm{NC}$} & Masters Degree & 61 & 15.3934 & 3.6436 & .4665 & 14.4603 & 16.3266 & 6.00 & 23.00 \\
\hline & Other & 2 & 15.5000 & 7.7782 & 5.5000 & -54.3841 & 85.3841 & 10.00 & 21.00 \\
\hline & Qualifications & & & & & & & & \\
\hline & Total & 287 & 16.8014 & 4.7252 & .2789 & 16.2524 & 17.3504 & 6.00 & 30.00 \\
\hline
\end{tabular}

Note. OC: Organizational Commitment; AC: Affective Commitment; CC: Continuance Commitment; NC: Normative Commitment; N: Number of respondents; SD: Standard Deviation; SE: Standard Error.

In Table 9 below, a strong evidence of statistical significances (at $<0.05)$ level exist in this relationship. The significance level for each component of commitment was (affective (0.000), continuance (0.19) and normative (.002)). This still lends credence to the earlier assertion that those with higher level of education such as the Masters degree are not as committed as employees with lower level of education, i.e. first (or bachelors) degree. Accordingly, this study rejects the third hypothesis that employees with higher level of education will report a higher level of commitment. This result corresponds with that of Martin and Roodt (2008) which found a significant relationship between commitment and academic qualification stating that organizational commitment decreased as education level increased. Yew (2008) also indicated a negative relationship between education level and affective commitment and Zaitouni et al. (2011) reported that there was no obvious relationship. Education was found to have a little effect on organizational commitment by Mottaz (1988). However, Adenuga, et al., (2013) in his survey of 600 participants from private universities in Ogun State, Nigeria found educational qualifications to be the most potent factor predicting organizational commitment.

Table 9. One-way ANOVA of employee commitment on education analysis

\begin{tabular}{ccccccc}
\hline $\begin{array}{c}\text { Dimensions of } \\
\text { OC }\end{array}$ & & Sum of Squares & df & Mean Square & F & Sig. \\
\hline AC & Between Groups & 725.234 & 3 & 241.745 & 6.204 & .000 \\
& Within Groups & 10793.115 & 277 & 38.964 & & \\
& Total & 11518.349 & 280 & & & \\
CC & Between Groups & 500.869 & 3 & 166.956 & 3.376 & .019 \\
& Within Groups & 13995.103 & 283 & 49.453 & & \\
& Total & 14495.972 & 286 & & & .002 \\
$\mathrm{NC}$ & Between Groups & 337.002 & 3 & 122.334 & 5.256 & \\
& Within Groups & 6048.677 & 283 & 21.373 & & \\
\hline
\end{tabular}

Note. OC: Organizational Commitment; AC: Affective Commitment; CC: Continuance Commitment; NC: Normative Commitment; df: Degree of Freedom; Sig.: Level of Significance.

Grusky (1966) used the factors of rewards and costs to explain the link between level of education and commitment. He suggested that these two factors - rewards and costs - influence a person's strength of attachment to an organization. He found female and less educated managers to be more committed to the organization as they overcame bigger hurdles (costs) to achieve the career mobility (rewards) than did the male and the managers possessing more formal education (see He, 2008). In his own study, focusing on staff in assisted living, Sikorska-Simmons (2004) found education to be one of the strong predictors of commitment.

\section{Implications of Result and Suggestions for Future Research}

This study has implications for human resource management as well as for researchers. In the $21^{\text {st }}$ century highly competitive business environment people hold the key to sustainable competitive advantage. The use of age and experience as promotion and selection criteria should be applied with caution. A flexible instead of a rigid approach could help organizations to hire candidates and promote highly productive employees regardless of their age and length of service. Reward for performance is more likely to enhance productivity than seniority-based promotion. Winning the commitment of employees is a task that should be deliberately, carefully and painstakingly approached. Instead of a 'one cap fits all' or generalized approach, each employee's peculiar needs should be identified and given proper attention.

For researchers, consultants and academics, a further empirical study of the role of employee personal 
characteristics and their influence on job involvement especially organizational commitment is suggested. Results from further empirical studies could make generalizations possible since very few studies, with inconsistent results, are currently available in the context of financial institutions and Nigeria as a country.

It is also pertinent to note that culture-sensitive non-Western scales are essential to critically examine the attitudinal and behavioral tendencies of non-Western and developing country subjects. The current study employed a Western originated valid and reliable instrument which may not be totally applicable to other (especially African) cultures. It is therefore suggested that organizations take the role of culture into consideration when developing and implementing people management strategies, policies and practices that are aimed at fostering employee commitment.

\section{References}

Abdul-Nasiru, I., Mensah, R., Amponsah-Tawiah, K., Simpeh, K. N., \& Kumasey, A. S. (2014). Organisational commitment in the public service of Ghana - An Empirical Study. Developing Country Studies, 4(1), 49-55.

Abrams, D., Ando, K., \& Hinkle, S. (1998). Psychological attachment to the group: Crosscultural differences in organizational identification and subjective norms as predictors of workers' turnover intentions. Personality and Social Psychology Bulletin, 24(10), 1027-1039. http://dx.doi.org/ 10.1177/01461672982410001

Addae, H. M., \& Parboteeah, K. P. (2008). Role Stressors and Organizational Commitment: Public Sector Employment in St Lucia. International Journal of Manpower, 29(6), 727-743. http://dx.doi.org/10.1108/01437720810904220

Addae, H. M., Parboteeah, K. P., \& Davis, E. E. (2006). Organizational commitment and intentions to quit: An examination of the moderating effects of psychological contract breach in Trinidad and Tobago. International Journal of Organizational Analysis, 14(3), 225-238.

Adenguga, R. A., Adenuga, F. T., \& Ayodele, K. O. (2013). Organizational Commitment and Turnover Intention among Private Universities' Employees in Ogun State. Nigeria Open Journal of Education, 1(2), 31-36. http://dx.doi.org/10.12966/oje.05.04.2013

Allen, N. J., \& Meyer, J. P. (1990). The measurement and antecedents of affective, continuance and normative commitment to the organization. Journal of Occupational Psychology, 63(1), 1-18. http://dx.doi.org/ http://dx.doi.org/10.1111/j.2044-8325.1990.tb00506.x

Angle, H. L., \& Perry, J. L. (1981). An empirical assessment of organizational commitment and organizational effectiveness. Administrative Science Quarterly, 21, 1-14.

Best, P. W. (1994). Locus of control, personal commitment and commitment to the organization. Unpublished M.Com Thesis, University of South Africa, Pretoria.

Boon, O. K., \& Safa, M. S. (2006). TQM practices and affective commitment: A case of Malaysian semiconductor packaging organizations. International Journal of Management and Entrepreneurship, 2(1), $37-55$.

Buchanan, B. (1974). Building organizational commitment: The socialization of managers in work organization. Administrative Science Quarterly, 19, 533-546.

Chughtai, A. A., \& Zafar, S. (2006). Antecedents and consequences of organizational commitment among Pakistani university teachers. Applied HRM Research, 11(1), 39-64.

Chui, J., Tong, C., \& Mula, J. M. (2007). Assessing the extent to which career development impacts employee commitment: a case study of the ICT industry in Hong Kong. ACIS 2007 Proceedings. Retrieved from http://aisel.aisnet.org/acis2007/79

Cohen, A. (1993). Organisational commitment and turnover: a meta-analysis. Academy of Management Journal, 36(5), 1140-1159. http://dx.doi.org/10.2307/256650

Garson, D. (1998). Statnotes: Topics in Multivariate Analysis. Retrieved from http://www2.chass.ncsu.edu/garson/pa765/statnote.htm

Grusky, D. (1966). Career mobility and organizational commitment. Administrative Science Quarterly, 10, 488-503.

Hart, D., \& Willower, D. (2001). Principals' organizational commitment and school environmental robustness. Journal of Educational Research, 87(3), 174-179. http://dx.doi.org/ 10.1080/00220671.1994

He, P. (2008). An Investigation of the Antecedents and Consequences of Affective Commitment in a U.S. 
Hospitality Organization. Dissertation submitted to the Faculty of the Virginia Polytechnic Institute and State University in partial fulfillment of the requirement for the degree of Philosopy in Hospitality and Tourism Management. Blacksburg, Virginia.

Hunt, S. D., Wood, V. R., \& Chonko, L. B. (1989). Corporate Ethical Values and Organizational Commitment in Marketing. Journal of Marketing, 53, 79-90. http://dx.doi.org/10.5539/jms.v2n1p43

Kanter, R. M. (1968). Commitment and social organizations: A study of commitment mechanisms in utopian communities. American Sociological Review, 33, 499-517. http://dx.doi.org/10.2307/2092438

Kura, K. M., Abubakar, R. A., Abdullahi, S. A., \& Akpan, A. B. (2012). Influence of job satisfaction and demographic factors on organizational commitment among teachers of Federal Government Girls' College, Zaria, Nigeria. Journal of Management Science, 2(4), 11-23.

Mathieu, J. E., \& Zajac, D. M. (1990). A Review and Meta-analysis of the Antecedents, Correlates, and Consequences of Organisational Commitment. Psychological Bulletin, 108, 171-194. Retrieved from http://doi.apa.org/journals/bul/108/2/171.pdf

Meyer, J. P., \& Allen, N. J. (1984). Testing the 'side-bet theory' of organizational commitment: Some methodological considerations. Journal of Applied Psychology, 69, 372-378. http://dx.doi.org/10.1037//0021-9010.69.3.372

Meyer, J. P., Allen, N. J., \& Gellatly, L. R. (1990). Affective and continuance commitment to the organization: Evaluation of measures and analysis of concurrent and time-lagged relations. Journal of Applied Psychology, 75, 710-720. http://doi.apa.org/journals/apl/75/6/710.pdf

Meyer, J. P., \& Allen, N. J. (1991). A three-component conceptualization of organizational commitment. Human Resources Management Review, 1, 61-89. http://dx.doi.org/ 10.1016/1053-4822(91)90011-Z

Meyer, J. P., \& Allen, N. J. (1997). Commitment in the Workplace: Theory, Research and Application. Thousands Oaks. Sage.

Meyer, J. P., \& Herscovitch, L. (2001). Commitment in the workplace: Toward a general model. Human Resource Review, 11(3), 299-326.

Meyer, J. P., Stanley, D. J., Herscovitch, L., \& Topolnytsky, L. (2002). Affective, Continuance and Normative Commitment to the Organization: A Meta-analysis of Antecedents, Correlates, and Consequences. Journal of Vocational Behavior, 61, 20-52. http://dx.doi.org/ 10.1006/jvbe.2001.1842

Mottaz, C. J. (1988). Determinants of organizational commitment. Human Relations, 41, 467-482. http://dx.doi.org/10.1177/001872678804100604

Mowday, R. T., Steers, R. M., \& Porter, L. W. (1979). The measure of Organizational Commitment. Journal of Vocational Behavior, 14, 224-247. http://dx.doi.org/10.1016/0001-8791(79)90072-1

Mowday, R. T., Porter, L. W., \& Steers, R. M. (1982). Employee-organization linkages: the psychology of commitment, absteeism, and turnover. Academic Press, London.

Morris, J. H., \& Sherman, J. D. (1981). Generalizability of an organizational commitment model. Academy of Management Journal, 24, 512-526. http://dx.doi.org/10.2307/255572

Ogba, I. (2008). Commitment in the workplace: The impact of income and age on employee commitment in Nigerian banking sector. Management Research News, 47(11), 867-878. http://dx.doi.org/10.1108/01409170810913051

Oxford English Dictionary. (1969). Oxford: Oxford University Press.

Herscovitch, L., \& Meyer, J. P. (2002). Commitment to organizational change: extension of a three-component model. The Journal of Applied Psychology, 87(3), 474-487. http://dx.doi.org/ 10.1037//0021-9010.87.3.474. 474

Reddy, N. Y., \& Ravikumar, R. (1980). Job attitude in lower management, involvement, motivation and capacity for satisfaction. Managerial Psychology, 1, 171-180.

Reichers, A. E. (1985). A review and reconceptualization of organizational commitment. Academy of Management Review, 10, 465-476.

Rhodes, S. R. (1983). Age related differences in work attitudes and behaviour: A review and conceptual analysis. Psychological Bulletin, 93, 328-367. http://dx.doi.org/ 10.1037/0033-2909.93.2.328 
Sa Abreu, M. C., Cunha, M. C., \& Reboucas, S. M. P. (2013). Effects of personal characteristics on organizational commitment: evidence from Brazil's oil and gas industry. The International Journal of Human Resource Management. http://dx.doi.org/10.10.1080/09585192.2013.781527

Salami, O. S. (2008). Demographic and psychological factors predicting organizational commitment among industrial workers. Anthropologist, 10(1), 31-38.

Sepahvand, T., Guilani, B., \& Zamani, R. (2007). Relationship between Attributional Styles with Stressful Life Events and General Health. Journal of Psychological Research, 9(3\&4), 33-46

Sheldon, M. E. (1971). Investments and involvements as mechanisms producing commitment to the organization. Administrative Science Quarterly, 16(2), 143-150.

Sikorska-Simmons, E. (2005). Predictors of organizational commitment among staff in assisted living. The Gerontologist, 45(2), 196-205. http://dx.doi.org/10.1093/geront/45.2.196

Singhal, S., \& Sood, R. (1981). Control in hospital and occupational commitment of nurses. Managerial Psychology, 2, 51-59.

Steers, R. M. (1977). Antecedents and outcomes of organizational commitment. Administrative Science Quarterly, 22, 46-56.

Wiener, Y., \& Vardi, Y. (1980). Relationships between job, organization and work outcomes: An Integrative approach. Organizational Behavior and Human Performance, 26, 81-96. http://dx.doi.org/10.1016/0030-5073(80)90048-3

Yew, L. T. (2008). Job Satisfaction and Affective Commitment: A Study of Employees in the Tourism Industry in Sarawak, Malaysia. World Review of Entrepreneurship, Management and Sustainable Development, 4(1), 85-101. http://dx.doi.org/ 10.1504/WREMSD.2008.016210

Yousef, D. A. (2000). Organizational commitment as a mediator of the relationship between Islamic work ethic and attitudes toward organizational change. Human Relations, 53(4), 513-537. http://dx.doi.org/10.5539/ibr.v6n12p107

Zaitouni, M., \& Sawalha, N. N. (2011). The Impact of Human Resource Management Practices on Organizational Commitment in the Banking Sector in Kuwait. International Journal of Business and Management, 6(5), 108-123. http://dx.doi.org/ 10.5539/ijbm.v6n6p108

\section{Copyrights}

Copyright for this article is retained by the author(s), with first publication rights granted to the journal.

This is an open-access article distributed under the terms and conditions of the Creative Commons Attribution license (http://creativecommons.org/licenses/by/3.0/). 